\title{
Kinetics of the Phosphorylation of Na,K-ATPase by Inorganic Phosphate Detected by a Fluorescence Method ${ }^{\dagger}$
}

\author{
Hans-Jürgen Apell, ${ }^{*} \pitchfork$ Milena Roudna,${ }^{\ddagger}$ John E. T. Corrie,${ }^{\S}$ and David R. Trentham ${ }^{\S}$ \\ Department of Biology, University of Konstanz, D-78434 Konstanz, Germany, and \\ National Institute for Medical Research, London NW7 1AA, England
}

Received January 31, 1996; Revised Manuscript Received June 10, $1996^{\otimes}$

\begin{abstract}
Phosphorylation by $\mathrm{P}_{\mathrm{i}}$ of the Na,K-ATPase from rabbit kidney in the absence of $\mathrm{Na}^{+}$ions but in the presence of $\mathrm{Mg}^{2+}$ ions has been studied. In the absence of $\mathrm{K}^{+}$ions, unphosphorylated and phosphorylated states induce different fluorescence levels in the membrane-bound styryl dye RH421, and hence transitions between the two states were monitored. Transient kinetic studies of phosphorylation were initiated by manual addition of $\mathrm{P}_{\mathrm{i}}$ or by photochemical release of $\mathrm{P}_{\mathrm{i}}$ from 1-(2-nitrophenyl)ethyl phosphate (caged $\mathrm{P}_{\mathrm{i}}$ ) using laser flash photolysis at $308 \mathrm{~nm}$. Equilibrium studies of phosphorylation showed that the apparent $K_{\mathrm{m}}$ for $\mathrm{P}_{\mathrm{i}}$ was $23.0 \pm 0.3 \mu \mathrm{M}$ (mean \pm sem) at $\mathrm{pH} 7.1$ and $21{ }^{\circ} \mathrm{C}$. The dye fluorescence increased in a biphasic manner on addition of $500 \mu \mathrm{M} \mathrm{P}_{\mathrm{i}}$ to the enzyme: a rapid phase $\left(t_{1 / 2}\right.$ $<1 \mathrm{~s}$ ) and a slower exponential phase at $0.059 \pm 0.003 \mathrm{~s}^{-1}$. The rate of the rapid phase was studied by fast concentration-jump experiments and exhibited first-order kinetics in $\mathrm{P}_{\mathrm{i}}$ up to $60 \mu \mathrm{M}$. Fluorescence records vs time were exponential, and a plot of the rate constant versus $\left[\mathrm{P}_{\mathrm{i}}\right]$ had a slope of $1.47 \times 10^{5}$ $\mathrm{M}^{-1} \mathrm{~s}^{-1}$ and ordinate $\left(\left[\mathrm{P}_{\mathrm{i}}\right]=0\right)$ intercept of $3.1 \mathrm{~s}^{-1}$. Addition of $50 \mathrm{mM} \mathrm{NaCl}$ to the phosphorylated enzyme induced an exponential decay in the dye fluorescence from which a rate constant of $0.10 \pm$ $0.005 \mathrm{~s}^{-1}$ was determined. These data were interpreted in terms of transformations between conformational states $\mathrm{E}_{1}$ and $\mathrm{E}_{2}$, and the phosphorylated state $\mathrm{P}-\mathrm{E}_{2}$ defined in the Post - Albers mechanism of the Na,K-ATPase [Läuger, P., (1991) Electrogenic Ion Pumps, Sinauer Associates Inc., Sunderland, MA] as follows: $\mathrm{E}_{1} \underset{k_{-1}}{\stackrel{k_{+1}}{\rightleftarrows}} \mathrm{E}_{2}+\mathrm{P}_{\mathrm{i}} \underset{k_{-2}}{\stackrel{k_{+2}}{\rightleftarrows}} \mathrm{P}-\mathrm{E}_{2}+\mathrm{H}_{2} \mathrm{O}$, where $k_{+1}=0.059 \mathrm{~s}^{-1}, k_{-1}=0.023 \mathrm{~s}^{-1}, k_{+2}=1.47 \times 10^{5} \mathrm{M}^{-1}$ $\mathrm{s}^{-1}$, and $k_{-2} \stackrel{k_{-1}}{=} 3.1 \mathrm{~s}^{-1}$. The RH421 fluorescence of state $\mathrm{P}-\mathrm{E}_{2}$ was studied over the $\mathrm{pH}$ range 6-8.5. Fluorescence was greatest at $\mathrm{pH} 8.5$ and lowest at $\mathrm{pH} 6.0$ in a simple binding isotherm with $\mathrm{p} K$ 7.5. The apparent $K_{\mathrm{m}}$ for $\mathrm{P}_{\mathrm{i}}$ rose cooperatively with increasing $\mathrm{pH}$ (pK $K_{\mathrm{a}} 8.6$ and a Hill coefficient of 2). Therefore in the absence of monovalent metal ions, occupation of the cation $\left(\mathrm{K}^{+}\right)$binding sites by protons promotes phosphorylation by $\mathrm{P}_{\mathrm{i}}$.
\end{abstract}

The Na,K-ATPase is an ion-transport protein of the plasma membrane which is found in nearly all animal cells. Under physiological conditions it hydrolyzes one molecule of ATP to move three $\mathrm{Na}^{+}$ions out of the cell and to import two $\mathrm{K}^{+}$ ions against the electrochemical potential gradients of each ion. The $\mathrm{Na}, \mathrm{K}-\mathrm{ATP}$ ase is characterized by its requirement for ATP, $\mathrm{Mg}^{2+}$, and $\mathrm{Na}^{+}$on the cytoplasmic side of the protein and $\mathrm{K}^{+}$on the extracellular side (Glynn, 1985; Jørgensen, 1992; Läuger, 1991). Scheme 1 shows that the transport cycle of the pump, usually termed the Post-Albers cycle, consists of a series of ordered reaction steps which comprise the three principal processes necessary to perform active pumping: (1) ion binding or release, (2) protein phosphorylation and dephosphorylation, and (3) conformational changes (Läuger, 1991). The transport functions can be modified by variation of the ionic composition at either membrane interface or by alteration of the phosphate source.

\footnotetext{
$\dagger$ This research was supported by grants from the Deutsche Forschungsgemeinschaft (Sonderforschungsbereich 156).

* Correspondence should be addressed to this author at the Department of Biology, University of Konstanz, Postfach 5560 M635, D-78434 Konstanz, Germany. FAX: +497531 883183.

* University of Konstanz.

$\S$ National Institute for Medical Research.

${ }^{\otimes}$ Abstract published in Advance ACS Abstracts, August 1, 1996.
}

Besides normal pumping, several noncanonical flux modes have been identified and utilized to investigate properties of partial reactions and to gain understanding of the pumping process (Glynn, 1985; Läuger, 1991): pump reversal (ATP synthesis), $3 \mathrm{Na}^{+} / 3 \mathrm{Na}^{+}$exchange (without net ATP hydrolysis), $2 \mathrm{~K}^{+} / 2 \mathrm{~K}^{+}$exchange (characterized by ${ }^{18} \mathrm{O}$ exchange between $\mathrm{P}_{\mathrm{i}}$ and water), uncoupled $\mathrm{Na}^{+}$efflux (3 $\mathrm{Na}^{+} /$zero exchange), and $3 \mathrm{Na}^{+} / 2 \mathrm{Na}^{+}$exchange (accompanied by ATP hydrolysis).

Here we extend these analyses of the Na,K-ATPase through investigation of the phosphorylation of the enzyme by $\mathrm{P}_{\mathrm{i}}$, the so-called "back-door" phosphorylation, that has previously been studied mainly by ${ }^{32} \mathrm{P}$-phosphorylation methods. It has been shown that $\mathrm{P}-\mathrm{E}_{2}$ formation from $\mathrm{P}_{\mathrm{i}}$ can occur provided $\mathrm{Na}^{+}$is absent (Campos \& Beaugé, 1994; Cornelius, 1995; Post et al., 1975). Phosphorylation from $\mathrm{P}_{\mathrm{i}}$ or ATP results in chemically identical phosphoenzymes (Bonting et al., 1979; Berberián \& Beaugé, 1991). On this basis back-door phosphorylation represents the reversal of the hydrolysis step of the phosphoenzyme under physiological conditions. Phosphorylation from $\mathrm{P}_{\mathrm{i}}$ or from ATP requires $\mathrm{Mg}^{2+}$ (Post et al., 1975). $\mathrm{P}_{\mathrm{i}}$ and ATP compete with each other for the enzyme, and so mutually influence their respective $K_{\mathrm{m}}$ values (Campos \& Beaugé, 1994). Back-door phosphorylation can in principle be split 
Scheme 1: Post-Albers Scheme of the Pump Cycle of Na,K-ATPase under Physiological Conditions, Adapted from Wuddel and Apell (1994) ${ }^{a}$

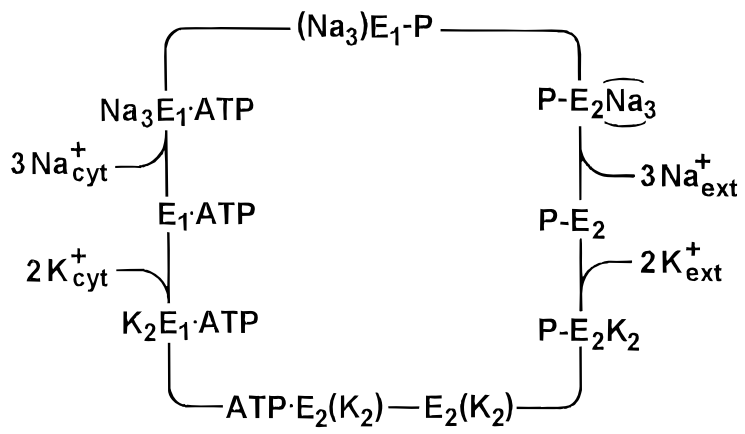

${ }^{a} E_{1}$ and $E_{2}$ are conformations of the enzyme with binding sites facing the cytoplasm and the extracellular medium, respectively. In the occluded states $\left(\mathrm{Na}_{3}\right) \mathrm{E}_{1}-\mathrm{P}, \mathrm{E}_{2}\left(\mathrm{~K}_{2}\right)$, and $\mathrm{ATP} \cdot \mathrm{E}_{2}\left(\mathrm{~K}_{2}\right)$, the bound ions are unable to exchange with the aqueous phase. The horizontal parentheses in state $\mathrm{P}-\mathrm{E}_{2} \mathrm{Na}_{3}$ indicate that in this state the ion sites are accessible only through a narrow well. Dashes indicate covalent bonds, and dots indicate noncovalent bonds. When the enzyme is phosphorylated by ATP in state $\mathrm{E}_{1}$, three $\mathrm{Na}^{+}$ions become occluded $\left(\mathrm{Na}_{3} \mathrm{E}_{1} \cdot \mathrm{ATP} \rightarrow\left(\mathrm{Na}_{3}\right) \mathrm{E}_{1}-\mathrm{P}\right)$. The spontaneous transition to conformation $\mathrm{E}_{2}$ leads to release of the $\mathrm{Na}^{+}$ions to the extracellular side. This is followed by subsequent binding of potassium, which initiates enzyme dephosphorylation and occlusion of $\mathrm{K}^{+}$ions. Low-affinity binding of ATP shifts the conformation to state $\mathrm{E}_{1}$, from which $\mathrm{K}^{+}$is released to the cytoplasm.

into two reaction steps:

$$
\begin{gathered}
E_{1} \underset{k_{-1}}{\stackrel{k_{+1}}{\rightleftarrows}} E_{2} \\
\mathrm{E}_{2}+\mathrm{P}_{\mathrm{i}} \underset{k_{-2}}{\stackrel{k_{+2}}{\rightleftarrows}} \mathrm{P}-\mathrm{E}_{2}+\mathrm{H}_{2} \mathrm{O}
\end{gathered}
$$

Reaction 1 is accelerated by ATP in the $\mathrm{K}^{+}$pathway of the normal pump mode (i.e., $\mathrm{E}_{2} \rightarrow \mathrm{E}_{1}$ ) (Campos \& Beaugé, 1994), but not in the $3 \mathrm{Na}^{+} / 2 \mathrm{Na}^{+}$exchange mode, at least in reconstituted systems (Apell et al., 1990).

We have investigated the kinetics and equilibria of enzyme phosphorylation by $\mathrm{P}_{\mathrm{i}}$ and determined the net charge of the ion-binding domain in this pathway. The use of a photosensitive "caged" phosphate allowed synchronization of pump function by imposing a phosphate concentration jump. Back-door phosphorylation was monitored by changes in the fluorescence of the styryl dye RH42 $1^{1}$ that has previously been used to investigate the occupation of the extracellularlypresented binding sites in the Na,K-ATPase (Bühler \& Apell, 1995; Heyse et al., 1994; Stürmer et al., 1991a). The dye is thought to insert into the lipid domains of Na,K-ATPase membrane fragments and to detect changes of electric field strength inside the membrane dielectric but not conformational transitions (Bühler et al., 1991). Such changes in electric field strength are caused by binding or release of ions and/or by movement of charge inside the membrane. The fluorescence levels allow discrimination between differently charged states of the enzyme and the fluorescence change between states can be assumed to be proportional to the change of the electric field in the membrane (Bühler et al., 1991; Grinvald et al., 1982). Back-door phosphorylation can occur whether $\mathrm{K}^{+}$ions are present or not (Post et al.,

${ }^{1}$ Abbreviations: DEAE cellulose, (diethylamino)ethyl cellulose; HPLC, high-performance liquid chromatography; RH421, N-(4-sulfobutyl)-4-[4-( $p$-(dipentylamino)phenyl)butadienyl]pyridinium, inner salt; Tris, tris(hydroxymethyl)aminomethane.
1975; Sen et al., 1969). In the absence of $\mathrm{K}^{+}$the cation binding sites are (partly) empty, so the steady state of the $\mathrm{Na}, \mathrm{K}-\mathrm{ATPase}$ after phosphorylation can be detected by RH421 as the accompanying charge change is uncompensated.

For the most part results are interpreted in terms of reactions 1 and 2. Experimental protocols are described which enable these noncanonical flux modes of the ATPase to be monitored. These modes are related to the reverse of the normal mode of the pump from $\mathrm{K}_{2} \mathrm{E}_{1} \cdot \mathrm{ATP}$ to $\mathrm{P}-\mathrm{E}_{2}$ (Scheme 1) when ATP and $\mathrm{K}^{+}$ions are absent.

\section{MATERIALS AND METHODS}

Materials. Sodium dodecyl sulfate was obtained from Pierce Chemical, Rockford, IL. Phosphoenolpyruvate, pyruvate kinase, lactate dehydrogenase, NADH, and ATP (disodium salt, special quality) were from Boehringer Mannheim. RH421 was from Molecular Probes, Eugene, OR. Dye purity was checked by thin-layer chromatography. Purine nucleoside phosphorylase was the "bacterial" protein from Sigma, and MESG (2-amino-6-mercapto-7-methylpurine ribonucleoside) was a gift from Dr. Martin Webb. All other reagents were at least analytical grade.

Preparation of Membrane Fragments Containing Na,KATPase. Na,K-ATPase was prepared from the outer medulla of rabbit kidneys using procedure C of Jørgensen (1974). The specific ATPase activity was measured by the pyruvate kinase/lactate dehydrogenase assay (Schwartz et al., 1971), and the protein concentration was determined by the method of Lowry et al. (1951), using bovine serum albumin as a standard. For most preparations the specific activity was in the range $1900-2000 \mu \mathrm{mol}$ of $\mathrm{P}_{\mathrm{i}}$ formed per hour and $\mathrm{mg}$ of protein at $37^{\circ} \mathrm{C}$.

Synthesis of Caged Inorganic Phosphate. ( \pm )-1-(2Nitrophenyl)ethanol (1 mmol) was phosphorylated as previously described for the separate $(+)$ - and (-)-enantiomers (Corrie et al., 1992), except that instead of precipitating the product as its $\mathrm{Ba}^{2+}$ salt, it was isolated by anion-exchange chromatography on a column of DEAE cellulose $(2 \times 40$ $\mathrm{cm})$ eluted with a linear gradient formed from 10 and 200 $\mathrm{mM}$ triethylammonium bicarbonate (each $1000 \mathrm{~mL}$ ). Fractions containing the caged phosphate were evaporated under reduced pressure and then evaporated an additional three times with methanol to remove excess triethylamine. The recovered material (triethylammonium salt) was converted to its $\mathrm{Li}^{+}$salt by exchange with Dowex $50\left(\mathrm{Li}^{+}\right.$form) and stored at $-20{ }^{\circ} \mathrm{C}$.

Fluorescence Measurements. An ethanolic stock solution of the fluorescent styryl dye RH421 was added to the aqueous suspension of membrane fragments to obtain a final concentration of 200-250 nM. Steady-state fluorescence measurements or those involving manual additions (e.g., Figure 1) were carried out with a Perkin Elmer LS50B luminescence spectrometer. In a typical experiment the cell contained a suspension of membrane fragments containing $5-15 \mu \mathrm{g}$ of $\mathrm{Na}, \mathrm{K}$-ATPase per mL (i.e., 0.03-0.1 $\mu \mathrm{M}$; Ovchinnikov et al., 1986) in a standard solution at $21 \pm 1{ }^{\circ} \mathrm{C}$ containing $230 \mathrm{nM}$ RH421, $10 \mathrm{mM} \mathrm{MgCl}$, $0.1 \mathrm{mM}$ EDTA, $25 \mathrm{mM}$ histidine adjusted to $\mathrm{pH} 7.1 \pm 0.1$ with $\mathrm{HCl}$. Other reagents were added as specified. The thermostated cell holder was equipped with a magnetic stirrer. The excitation wavelength was set to $580 \mathrm{~nm}$ (slit width $15 \mathrm{~nm}$ ), and the emission wavelength was set to $650 \mathrm{~nm}$ (slit width $15 \mathrm{~nm}$ ). 


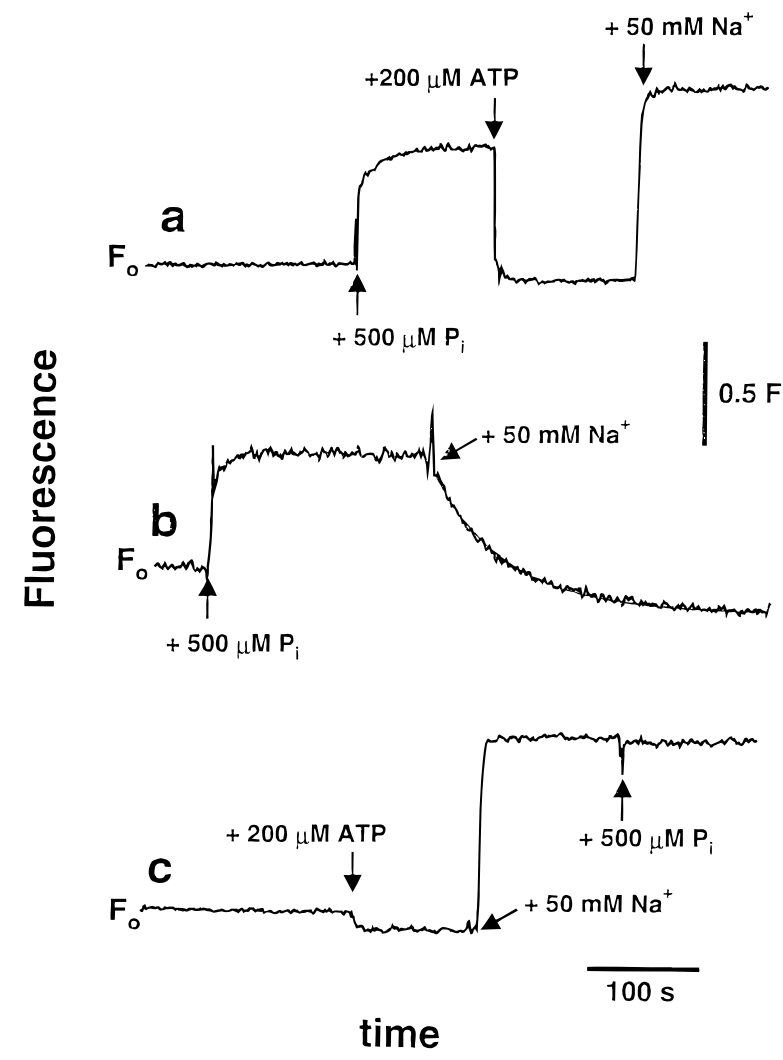

FIGURE 1: Comparison of the effects of $\mathrm{P}_{\mathrm{i}}$ and ATP on the Na,KATPase. The enzyme and RH421 in $10 \mathrm{mM} \mathrm{MgCl}_{2}, 0.1 \mathrm{mM}$ EDTA, $25 \mathrm{mM}$ histidine adjusted to $\mathrm{pH} 7.1 \pm 0.1$ were incubated at $21 \pm$ $1{ }^{\circ} \mathrm{C}$ as described in Materials and Methods. $\mathrm{P}_{\mathrm{i}}$, ATP (each as Tris salts), and $\mathrm{NaCl}$ were added as indicated during time records of RH421 fluorescence. Interpretation of the changes following the additions is in the text. $F_{0}$ is the fluorescence of RH421 bound to the membrane. RH421 fluorescence is recorded on successive additions of (a) $\mathrm{P}_{\mathrm{i}}, \mathrm{ATP}$, and $\mathrm{NaCl}$, (b) $\mathrm{P}_{\mathrm{i}}$ and $\mathrm{NaCl}$, and (c) ATP, $\mathrm{NaCl}$, and $\mathrm{P}_{\mathrm{i}}$.

Transient fluorescence signals produced by photochemical release of $\mathrm{P}_{\mathrm{i}}$ from its precursor, caged $\mathrm{P}_{\mathrm{i}}$, were measured as described previously for experiments with caged ATP, the $P^{3}$-1-(2-nitrophenyl)ethyl ester of ATP (Stürmer et al., 1989). The optical cell was filled with $200-300 \mu \mathrm{L}$ of the solution described above plus 5-600 $\mu \mathrm{M}$ caged $\mathrm{P}_{\mathrm{i}}$. After thermal equilibration at $21^{\circ} \mathrm{C}$, the fluorescence signal was monitored. Fluorescence was excited by light from a $250 \mathrm{~W}$ tungstenhalogen lamp, and emitted light from the sample cell was collected by an ellipsoidal mirror and focused onto the cathode of the photomultiplier. Excitation $(580 \mathrm{~nm})$ and emission $(650 \mathrm{~nm})$ wavelengths were selected by interference filters (13 nm bandwidth). The current signal of the photomultiplier was converted to voltage, digitized by a 16bit analog-to-digital converter (DSP 32C Loughborough Sound Images Ltd., Loughborough, Leics LE11 0QE, England), and stored on the hard disk of a personal computer. $\mathrm{P}_{\mathrm{i}}$ was released in the cuvette from caged $\mathrm{P}_{\mathrm{i}}$ by a light flash (wavelength, $308 \mathrm{~nm}$; total energy, $150 \mathrm{~mJ}$; duration, $10 \mathrm{~ns}$ ) generated by an EMG 100 excimer laser (Lambda Physik, Göttingen). The rate constant for $\mathrm{P}_{\mathrm{i}}$ release on photolysis of caged $\mathrm{P}_{\mathrm{i}}$ at $\mathrm{pH} 7.1$ and $21{ }^{\circ} \mathrm{C}$ is approximately $3 \times 10^{4}$ $\mathrm{s}^{-1}$ (Dantzig et al., 1992).

Determination of Released $P_{i}$. Buffer solutions containing flash-photolyzed caged $P_{i}$ were analyzed by HPLC by a method adapted from Corrie and Trentham (1992). Samples were injected in a Millipore-Waters equipment and chro- matographed by a Whatman Partisphere SAX column (cat. no. 4621-0505) with mobile-phase flow rate at $1.5 \mathrm{~mL} / \mathrm{min}$ and UV detection at $254 \mathrm{~nm}$. The mobile-phase buffer contained $125 \mathrm{mM}\left(\mathrm{NH}_{4}\right) \mathrm{H}_{2} \mathrm{PO}_{4}$ and $10 \%$ methanol (adjusted to $\mathrm{pH} 6.2$ with $\mathrm{NaOH}$ ). When samples containing protein were investigated, the suspension was centrifuged to remove the membrane fragments prior to injection onto the column. The peak areas of the caged compound before and after illumination were determined, and the yield of the release reaction was calculated from the initial concentration and the ratio of the areas. The conversion efficiency was 10.5 $\pm 0.4 \%$. That the released $P_{i}$ was equal to the photolyzed caged $P_{i}$ was established by measurement of released $P_{i}$ in control experiments using a $\mathrm{P}_{\mathrm{i}}$ colorimetric assay (Webb, 1992).

\section{RESULTS}

Generation of $P-E_{2}$ from $P_{i}$ and from ATP and Its Hydrolysis. Figure 1 shows several protocols during which RH421 fluorescence is monitored. Thus in Figure 1a, 230 $\mathrm{nM} \mathrm{RH} 421$ and $9 \mu \mathrm{g}$ of Na,K-ATPase $/ \mathrm{mL}$ were added to the standard buffer and equilibrated until the fluorescence reached a constant level, presumably that of a mixture of $E_{1}$ and $\mathrm{E}_{2}$. At this point $500 \mu \mathrm{M}$ Tris phosphate was added. $\mathrm{P}_{\mathrm{i}}$ caused a fluorescence increase of $55 \%$, qualitatively in agreement with a change to $\mathrm{P}-\mathrm{E}_{2}$ (Schwappach et al., 1994) via reactions 1 and 2 .

Addition of ATP causes apparent hydrolysis of $\mathrm{P}-\mathrm{E}_{2}$ through the reaction sequence $\mathrm{P}-\mathrm{E}_{2} \rightarrow \mathrm{E}_{2} \rightarrow \mathrm{E}_{2} \cdot \mathrm{ATP} \rightarrow$ $\mathrm{E}_{1} \cdot \mathrm{ATP}$. Thus in Figure 1a, $200 \mu \mathrm{M}$ ATP induced a decrease of fluorescence to a low level characteristic of the state $\mathrm{E}_{1} \cdot \mathrm{ATP} . \quad 200 \mu \mathrm{M}$ ATP was shown to be saturating by repeating the protocol using lower ATP concentrations in titration experiments. The apparent $K_{\mathrm{m}}$ for ATP was 11.8 $\pm 0.2 \mu \mathrm{M}$ (mean \pm sem) (data not shown). Addition of 50 $\mathrm{mM} \mathrm{NaCl}$ to the ATP treated solution now caused an increase of fluorescence (Figure 1a) that was about 1.6-fold greater than the fluorescence increase induced by $\mathrm{P}_{\mathrm{i}} .50 \mathrm{mM} \mathrm{NaCl}$ is saturating on the cytoplasmic site of the enzyme $\left(K_{\mathrm{m}}=8\right.$ $\mathrm{mM}$ ). The second fluorescence increase is presumed to be caused by phosphorylation from ATP in agreement with the partial reaction $\mathrm{Na}_{3} \mathrm{E}_{1} \bullet \mathrm{ATP} \rightarrow \mathrm{P}-\mathrm{E}_{2}$ (Scheme 1; Stürmer et al., 1991a; Stürmer \& Apell, 1992). The different fluorescence levels for the $\mathrm{P}-\mathrm{E}_{2}$ states, obtained after phosphorylation by $\mathrm{P}_{\mathrm{i}}$ or ATP, will be investigated below.

Addition of saturating $\mathrm{Na}^{+}$to $\mathrm{P}-\mathrm{E}_{2}$ generates $\mathrm{Na}_{3} \mathrm{E}_{1}$ (Heyse et al., 1994). The rate of this process was measured by monitoring the fluorescence when $50 \mathrm{mM} \mathrm{NaCl}$ was added to $\mathrm{P}-\mathrm{E}_{2}$ generated by $\mathrm{P}_{\mathrm{i}}$ phosphorylation (Figure 1b). The rate constant for this exponential process of $\mathrm{Na}_{3} \mathrm{E}_{1}$ formation was $0.023 \pm 0.001 \mathrm{~s}^{-1}$ in the presence of $500 \mu \mathrm{M}$ $\mathrm{P}_{\mathrm{i}}$. Similar experiments were performed in the presence of $10-500 \mu \mathrm{M} \mathrm{P}_{\mathrm{i}}$. The observed rate constant depended on the $P_{i}$ concentration in agreement with the reaction sequence $\mathrm{P}-\mathrm{E}_{2} \rightleftarrows \mathrm{E}_{2}+\mathrm{P}_{\mathrm{i}} \rightarrow \mathrm{E}_{1}$ (data not shown). The rate constant determined as $\left[\mathrm{P}_{\mathrm{i}}\right] \rightarrow 0$ was $0.1 \mathrm{~s}^{-1}$. The much more rapid decay induced by ATP (Figure 1a) is consistent with a 200fold rate activation for the $E_{2} \rightarrow E_{1}$ conformational change found in the presence of $\mathrm{K}^{+}$(Heyse et al., 1994). Caged ATP which binds to the ATPase (Borlinghaus \& Apell, 1988; Forbush, 1984) also induced a rapid fluorescence decay confirming that ATP hydrolysis is not necessary for the process (data not shown). 
The different fluorescence levels induced by $500 \mu \mathrm{M} \mathrm{P}_{\mathrm{i}}$ and by $200 \mu \mathrm{M}$ ATP plus $50 \mathrm{mM} \mathrm{NaCl}$ are important in describing properties of the $\mathrm{P}-\mathrm{E}_{2}$ state (Figure 1a). In an altered protocol (Figure 1c), the solution with ATPase, RH421, and $200 \mu \mathrm{M}$ ATP was treated with $50 \mathrm{mM} \mathrm{NaCl}$ followed by $500 \mu \mathrm{M} \mathrm{P}$. The small drop in fluorescence upon addition of ATP is not specific since it can also be observed in the absence of $\mathrm{Mg}^{2+}$. Most probably it is caused by adsorption of ATP to the lipid domains of the membrane fragments. No fluorescence change occurred (after dilution correction) on $\mathrm{P}_{\mathrm{i}}$ addition. From these findings we propose that the phosphorylation in the presence of $\mathrm{Na}^{+}$ions produces a differently charged state of the protein. The relevance of this observation with respect to the amount of uncompensated charge within the protein dielectric is addressed in the section on $\mathrm{pH}$ dependence and in the Discussion. The data in Figure 1a and $\mathrm{c}$ also show that, in the absence of potassium ions, state $\mathrm{P}-\mathrm{E}_{2}$ in eq 2 is the steady-state intermediate of the ATPase.

Several control experiments were performed. Thus following the protocol of Figure 1a, no fluorescence change occurred on $\mathrm{P}_{\mathrm{i}}$ addition either in the absence of $\mathrm{Mg}^{2+}$ or in the presence of $50 \mathrm{mM} \mathrm{NaCl}$. Previously reported findings that the conformational change in the presence of $\mathrm{K}^{+}, \mathrm{E}_{1}+$ $2 \mathrm{~K} \rightarrow \mathrm{K}_{2} \mathrm{E}_{1} \rightarrow \mathrm{E}_{2}\left(\mathrm{~K}_{2}\right)$, is not accompanied by a fluorescence change (Stürmer et al., 1991a; Klodos, 1994) were verified. In standard solution or solutions containing $25 \mathrm{mM}$ imidazole instead of histidine the RH421 fluorescence was monitored while $20 \mathrm{mM} \mathrm{KCl}$ and $200 \mu \mathrm{M}$ were added successively and no significant fluorescence change was detected on either addition. To check the effect of protons on the RH421 fluorescence the $\mathrm{pH}$ was changed between 7.1 and 8.0 in standard solution by addition of $4 \mathrm{mM}$ Tris base and between $\mathrm{pH} 8.0$ and 6.6 by addition of $\mathrm{HCl}$ to standard solutions and to solutions containing $20 \mathrm{mM} \mathrm{NaCl}$ (to confine the protein in one state, $\mathrm{Na}_{3} \mathrm{E}_{1}$ ) or $20 \mathrm{mM} \mathrm{KCl}$ [to maintain state $\mathrm{E}_{2}\left(\mathrm{~K}_{2}\right)$ ]. Significant RH421 fluorescence changes could not be detected in any of these experiments. Therefore we conclude that binding of protons to ion binding sites or to amino acids, which are accessible to the aqueous phase, does not affect the RH421 fluorescence in unphosphorylated states of the protein as has been demonstrated previously (Klodos, 1994).

RH421 Signals Associated with the Dependence of BackDoor Phosphorylation on $P_{i}$ Concentration. To explore further the nature of phosphorylation by $\mathrm{P}_{\mathrm{i}}$, equilibrium titration experiments were performed in standard buffer containing $230 \mathrm{nM} \mathrm{RH} 421$ and $9 \mu \mathrm{g}$ of Na,K-ATPase $/ \mathrm{mL}$. Aliquots of a concentrated solution of Tris phosphate were added and the fluorescence was measured relative to the initial level, $F_{0}$. Results are shown in Figure 2. The line represents a fit of a simple binding isotherm to the averaged data of three titrations with the same enzyme preparation. Such experiments were repeated with four different preparations. The average half-saturating concentration, $K_{\mathrm{m}}$, of the phosphorylation reaction was $23.0 \pm 0.3 \mu \mathrm{M}$ at $\mathrm{pH} 7.1$ and $21^{\circ} \mathrm{C}$. Titration experiments performed with $10 \mathrm{mM}$ Tris initially present did not show a significant change in the measured $K_{\mathrm{m}}$ for $\mathrm{P}_{\mathrm{i}}$.

RH421 Signals Associated with the Kinetics of Phosphorylation of the Na,K-ATPase by $P_{i}$ : Slow Phase. Inspection of Figure 1a shows that addition of saturating $(500 \mu \mathrm{M}) \mathrm{P}_{\mathrm{i}}$ resulted in a biphasic fluorescence response. The ratio of

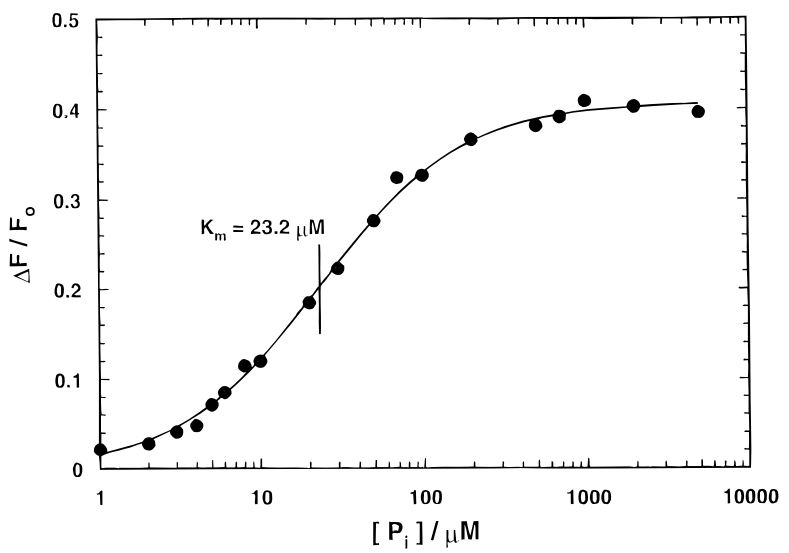

FIgURE 2: Titration of RH421 fluorescence changes induced by $\mathrm{P}_{\mathrm{i}}$ in standard buffer conditions. The relative fluorescence changes, $\Delta F / F_{0}$, were calculated with respect to the fluorescence intensity, $F_{0}$, prior addition of $\mathrm{P}_{\mathrm{i}}$. The experimental data were fitted by a Michaelis-Menten function, $\Delta F / F_{0}=\Delta F_{\max } / F_{0}\left(\left[\mathrm{P}_{\mathrm{i}}\right] /\left(K_{\mathrm{m}}+\left[\mathrm{P}_{\mathrm{i}}\right]\right)\right.$, with a maximum fluorescence increase $\Delta F_{\max } / F_{0}=0.41$ and the half-saturating concentration of phosphate $K_{\mathrm{m}}=23.2 \mu \mathrm{M}$.

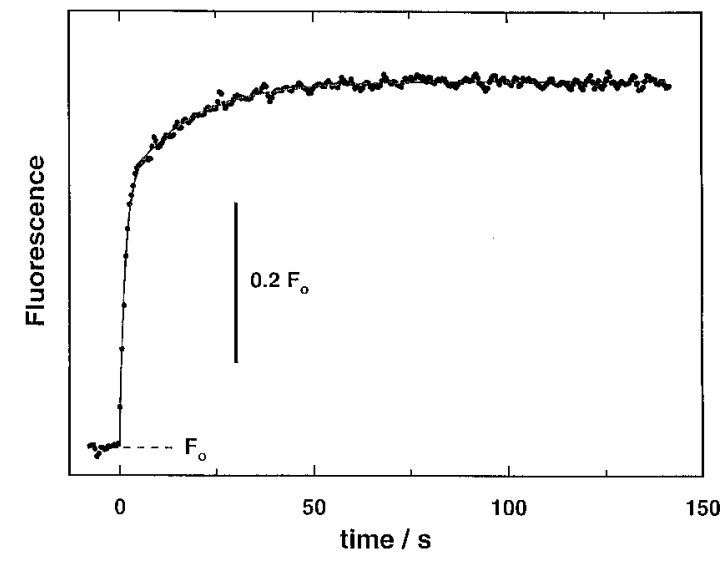

FIGURE 3: Time course of RH421 fluorescence upon addition of $500 \mu \mathrm{M} \mathrm{P} \mathrm{P}_{\mathrm{i}}$ at $t=0$ to the enzyme in standard buffer observed with higher time resolution than in Figure 1a. The fluorescence signal can be fitted by the sum of two exponentials. The fast process represents the mixing time of $\mathrm{P}_{\mathrm{i}}$ in the cuvette. The slower process with a rate constant of $0.058 \mathrm{~s}^{-1}$ is assigned to the conformational change $\mathrm{E}_{1} \rightarrow \mathrm{E}_{2}$ coupled to the more rapid $\mathrm{E}_{2}+\mathrm{P}_{\mathrm{i}} \rightarrow \mathrm{P}-\mathrm{E}_{2}$ step. The amplitude ratio of the fast to slow processes is 1.98 .

the amplitude of the fast and the slow phases and the rate of the slow phase were readily monitored following manual addition of $\mathrm{P}_{\mathrm{i}}$ to the enzyme in the presence of RH421 (Figure 3). As already stated we interpret the overall fluorescence increase to be due to $\mathrm{P}-\mathrm{E}_{2}$ formation via reactions 1 and 2. It follows that the fast phase is due to $\mathrm{P}-\mathrm{E}_{2}$ formation from $\mathrm{E}_{2}$ (reaction 2), and the slow phase is due to $E_{1}$ transformation to $E_{2}$ that is then rapidly converted to $\mathrm{P}-\mathrm{E}_{2}$. In terms of this model the ratio of the amplitudes of the fast and slow phase, measured to be $2.2 \pm 0.7$, corresponds to the ratio of $E_{2}$ to $E_{1}$ concentrations prior to $\mathrm{P}_{\mathrm{i}}$ addition (i.e., $k_{+1} / k_{-1}$ ).

The rate constant of the slow phase (i.e., $\mathrm{k}_{+1}$ ) was 0.059 $\pm 0.003 \mathrm{~s}^{-1}$. It has already been inferred from data such as in Figure $1 \mathrm{~b}$ that $k_{-1}$, the rate constant of $\mathrm{E}_{2} \rightarrow \mathrm{E}_{1}$, is 0.023 $\pm 0.001 \mathrm{~s}^{-1}$ in the presence of $500 \mu \mathrm{M} \mathrm{P}$. The ratio of the measured rate constants $(0.059 / 0.023)$ is $2.6 \pm 0.3$ and, as required by the model, equals within experimental error the amplitude ratio of $2.2 \pm 0.7$.

It is important to establish whether the $\mathrm{E}_{1}$ state identified here by the slow phase of the fluorescence change induced 
by $\mathrm{P}_{\mathrm{i}}$ corresponds to the $\mathrm{E}_{1}$ state identified in other experiments. Heyse et al. (1994) have estimated that the rate constant for the $E_{1}$ to $E_{2}$ isomerization in the presence of $\mathrm{K}^{+}$is $400 \mathrm{~s}^{-1}$ at $\mathrm{pH} 7.2$ and $20^{\circ} \mathrm{C}$. Schulz and Apell (1995) reported an apparent dissociation constant for $\mathrm{K}^{+}$of 0.15 $\mathrm{mM}$ from the $\mathrm{E}_{1}$ conformation of the same preparation. The rate constant for the putative $\mathrm{E}_{1}$ to $\mathrm{E}_{2}$ isomerization we have observed is $0.059 \mathrm{~s}^{-1}$. This is a rate constant that would be expected in the presence of $22 \mathrm{nM} \mathrm{K}^{+}\left(400 \mathrm{~s}^{-1} \times 0.022\right.$ $\left.\mu \mathrm{M} / 150 \mu \mathrm{M}=0.059 \mathrm{~s}^{-1}\right)$. Neglecting the effect of small differences of experimental conditions similar estimates can be made from the data published by Smirnova et al. (1995) on the $\mathrm{E}_{1}$ to $\mathrm{E}_{2}$ isomerization in the presence of $\mathrm{K}^{+}$. From their results a rate constant of $0.059 \mathrm{~s}^{-1}$ would be expected in the presence of $1.9 \mu \mathrm{M} \mathrm{K}^{+}$. The dependence of the rate constant of the slow phase of the fluorescence change induced by $\mathrm{P}_{\mathrm{i}}$ was analyzed over a $\mathrm{K}^{+}$concentration range from zero to $1 \mathrm{mM}$. The anticipated catalytic effect of $\mathrm{K}^{+}$ did not occur (data not shown) The observed rate constant decreased in an approximately linear fashion with $\left[\mathrm{K}^{+}\right]$from 0.059 to $0.03 \mathrm{~s}^{-1}$ between zero and $1 \mathrm{mM} \mathrm{K}^{+}$. We conclude therefore that, while the slow fluorescence change induced by $\mathrm{P}_{\mathrm{i}}$ may be associated with an $\mathrm{E}_{1}$ to $\mathrm{E}_{2}$ isomerization, there may well be subclasses of states within the well-characterized functionally and chemically distinguishable $E_{1}$ and $E_{2}$ conformations (Post et al., 1975).

RH421 Signals Associated with the Kinetics of Phosphorylation of the Na,K-ATPase by $P_{i}$ : Fast Phase. Manual addition of $\mathrm{P}_{\mathrm{i}}$ (Figures 1a and 3 ) was inadequate to determine the kinetics of the rapid phase of the RH421 fluorescence change. However, when $P_{i}$ was released by flash photolysis of caged $\mathrm{P}_{\mathrm{i}}$, a complex time course of the fast phase was seen (Figure 4, trace 1). In a control experiment caged $\mathrm{P}_{\mathrm{i}}$ was photolyzed as before, but with $\mathrm{MgCl}_{2}$ omitted from the solution. In this condition phosphorylation of the ATPase by $\mathrm{P}_{\mathrm{i}}$ will not occur. Trace 2 shows that a step decrease of fluorescence occurred, followed by a transient increase. Subtraction of trace 2 from trace 1 resulted in trace 3 and shows a small step increase, followed by the time course of the more rapid phase of the fluorescence change presumed to be due to phosphorylation of the ATPase by $\mathrm{P}_{\mathrm{i}}$. This phase of the trace could be described by a single exponential process with rate constant $k$.

In a further control experiment caged $\mathrm{P}_{\mathrm{i}}$ was omitted from the solution (now containing $10 \mathrm{mM} \mathrm{MgCl}$ ). The fluorescence record was identical to that in Figure 4 trace 2 except that the initial step decrease in fluorescence was much less. We conclude therefore that the transient shown in trace 2 is a property of the membrane bound dye when exposed to a UV-laser pulse. The mean time constant of this transient was $18.5 \pm 0.7 \mathrm{~ms}$ and, when recorded as in Figure 4, was independent of caged $\mathrm{P}_{\mathrm{i}}$ concentration. The initial step decrease in fluorescence was variable and could not be correlated with caged $\mathrm{P}_{\mathrm{i}}$ concentration.

Experiments as presented in Figure 4 were repeated at caged $\mathrm{P}_{\mathrm{i}}$ concentrations between 5.6 and $600 \mu \mathrm{M}$. In Figure 5 the rate constants, $k$, as observed in Figure 4 trace 3, are plotted against the concentration of the released $\mathrm{P}_{\mathrm{i}}$. The data points can be fitted by a straight line according to pseudofirst-order reaction kinetics:

$$
k=k_{+2}\left[\mathrm{P}_{\mathrm{i}}\right]+k_{-2}
$$

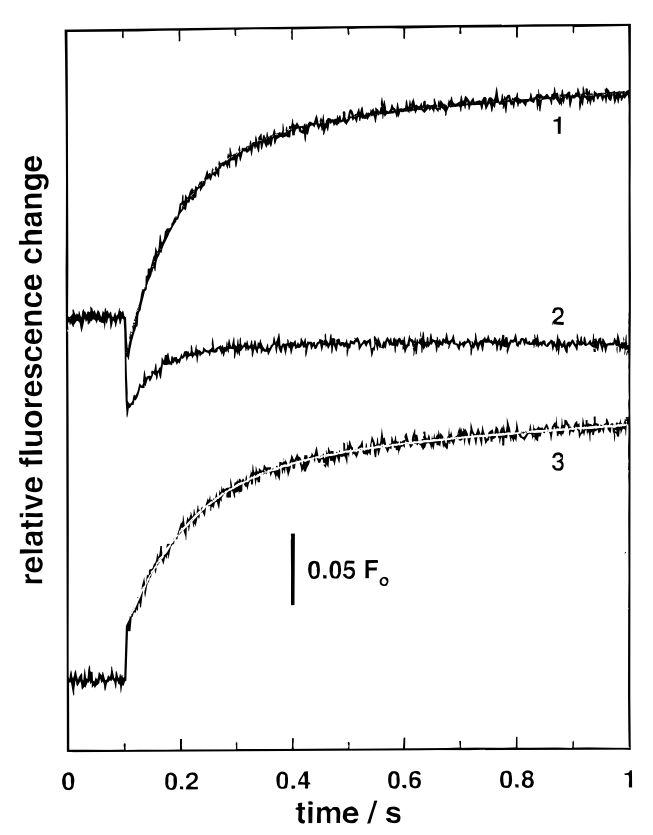

FIGURE 4: RH421 fluorescence following photorelease of $\mathrm{P}_{\mathrm{i}}$ from caged $\mathrm{P}_{\mathrm{i}}$. Trace 1 shows the fluorescence time course following flash photolysis of $129 \mu \mathrm{M}$ caged $\mathrm{P}_{\mathrm{i}}$ that released $17 \mu \mathrm{M} \mathrm{P}_{\mathrm{i}}$ in the solution as described in Materials and Methods. Trace 2 is an identical trial except that $10 \mathrm{mM} \mathrm{MgCl} 2$ was omitted. Trace 3 is a difference record of traces 1 and 2 . The solid line through trace 3 is the best fit to a single exponential plus a linear component of fluorescence versus time. This linear component is associated with the initial part of the slower phase of RH421 fluorescence response to $\mathrm{P}_{\mathrm{i}}$ (Figure 3).

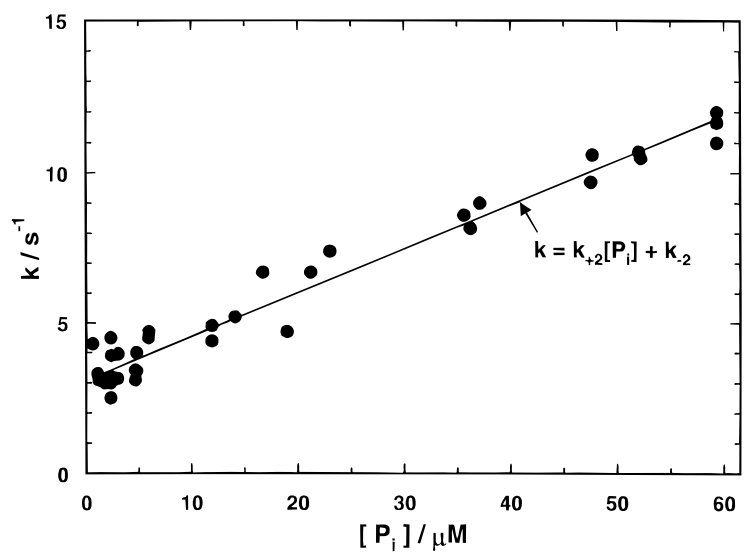

FIGURE 5: Dependence of the rate of the rapid phase of fluorescence increase on photoreleased $\mathrm{P}_{\mathrm{i}}$ concentration. The rate constants $k$ were obtained from traces such as Figure 4, trace 3. The regression line fitted to the data resulted in a slope of $1.47( \pm 0.05) \times 10^{5}$ $\mathrm{M}^{-1} \mathrm{~s}^{-1}$ and ordinate intercept of $3.07( \pm 0.17) \mathrm{s}^{-1}$.

where $k_{+2}$ and $k_{-2}$ are rate constants and $\left[\mathrm{P}_{\mathrm{i}}\right]$ is the concentration of $\mathrm{P}_{\mathrm{i}}$ after the light flash. Analysis of the data presented in Figure 5 gives $k_{+2}=1.47 \times 10^{5} \mathrm{M}^{-1} \mathrm{~s}^{-1}$ and $k_{-2}=3.1 \mathrm{~s}^{-1}$. Repetition of such experiments in buffers of $\mathrm{pH} 6.0$ or 8.1 did not change the slope of the line significantly (data not shown). $k_{+2}$ and $k_{-2}$ correspond with $r_{\mathrm{b}}$ and $r_{\mathrm{f}}$, respectively, in the kinetic model of Wuddel and Apell (1995).

The amplitudes of the exponential phases (e.g., Figure 4, trace 3 ) increased with increasing photoreleased $\left[\mathrm{P}_{\mathrm{i}}\right]$, consistent with the expected relationship:

$$
A_{1} / A_{2}=\left(1+k_{-2} / k_{+2}\left[\mathrm{P}_{\mathrm{i}}\right]_{2}\right) /\left(1+k_{-2} / k_{+2}\left[\mathrm{P}_{\mathrm{i}}\right]_{1}\right)
$$




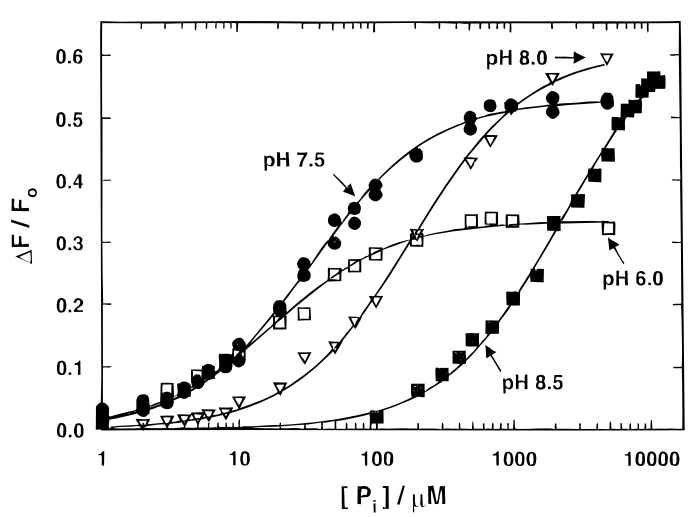

FIGURE 6: Dependence on $\mathrm{pH}$ of equilibrium binding of $\mathrm{P}_{\mathrm{i}}$ to the ATPase. The experiments were performed as in Figure 2 in the standard buffer in which $\mathrm{pH}$ values were adjusted by $\mathrm{HCl}$ or Tris. The data at $\mathrm{pH} 7.5$ represent two experiments to show typical scatter between data sets. The experimental data were fitted by simple binding isotherms. The different symbols distinguish the experiments.

where $A_{1}$ and $A_{2}$ are amplitudes from photoreleased concentrations $\left[\mathrm{P}_{\mathrm{i}}\right]_{1}$ and $\left[\mathrm{P}_{\mathrm{i}}\right]_{2}$ respectively.

RH421 Signals Associated with the Dependence of $P_{i}$ Phosphorylation on $\mathrm{pH}$. The phosphorylated proteins formed by reaction of the ATPase with ATP and with $\mathrm{P}_{\mathrm{i}}$ are chemically identical (Bonting et al., 1979), and the fluorescence increase that can be induced by $\mathrm{P}_{\mathrm{i}}$ is close to maximum at $500 \mu \mathrm{M} \mathrm{P}_{\mathrm{i}}$ addition (Figure 2). An explanation is required for the differences in fluorescence levels induced by $\mathrm{P}_{\mathrm{i}}$ and by ATP plus $\mathrm{NaCl}$ (Figure 1a) that may go beyond the presence of $\mathrm{Na}^{+}$in the latter case.

To check for a possible occupation of the ion-binding sites by protons, which would at least partly compensate the negative charges in the sites and in consequence reduce the level of fluorescence, the titration experiments were repeated at different $\mathrm{pH}$ values between 6 and 8.5. The buffer $\mathrm{pH}$ was adjusted by addition of $\mathrm{HCl}$ or Tris. A selection of the results is shown in Figure 6. At least four titration experiments were performed at each $\mathrm{pH}$ and averaged. Each series could be fitted well by a simple binding isotherm to determine both the corresponding maximum fluorescence changes $\left(\Delta F_{\max } / F_{0}\right)$, when the protein can be assumed to be completely phosphorylated, and the $K_{\mathrm{m}}$ values. In Figure 7 the $\mathrm{pH}$ dependence of these parameters is plotted as a function of $\mathrm{pH}$. Figure $7 \mathrm{a}$ shows that the fluorescence of the fully phosphorylated protein is $\mathrm{pH}$ dependent. As controls, the $\mathrm{pH}$ dependence of the RH421-labeled membrane fragments was determined in the absence of $\mathrm{P}_{\mathrm{i}}$ and also in the presence of $50 \mathrm{mM} \mathrm{NaCl}$ plus $500 \mu \mathrm{M}$ ATP. These conditions maintain the protein in the $\mathrm{E}_{1} / \mathrm{E}_{2}$ states and the $\mathrm{P}-\mathrm{E}_{2}$ state, respectively and in both cases the fluorescence did not change over the $\mathrm{pH}$ range 6.0-8.5. Therefore it can be assumed that the fluorescence changes are caused by alterations of the amount of uncompensated charge within the protein dielectric. The data in Figure $7 \mathrm{a}$ were fitted by a binding isotherm with a $\mathrm{p} K_{\mathrm{a}}$ of 7.5. This observation can be interpreted to mean that in the absence of $\mathrm{Na}^{+}$ions a proton may bind to the extracellularly-presented binding sites of the $\mathrm{P}-\mathrm{E}_{2}$ state of the Na,K-ATPase. At high $\mathrm{pH}$ the fluorescence ratio $\Delta F_{\max } / F_{0}$ approaches a value of 0.7 , which is close to that obtained (0.8) by phosphorylation with ATP in the presence of $\mathrm{NaCl}$. The dependence of the halfsaturating $\mathrm{P}_{\mathrm{i}}$ concentration on $\mathrm{pH}$ is shown in Figure $7 \mathrm{~b}$. For $\mathrm{pH}$ values above 7.5, a steep increase of the $K_{\mathrm{m}}$ was

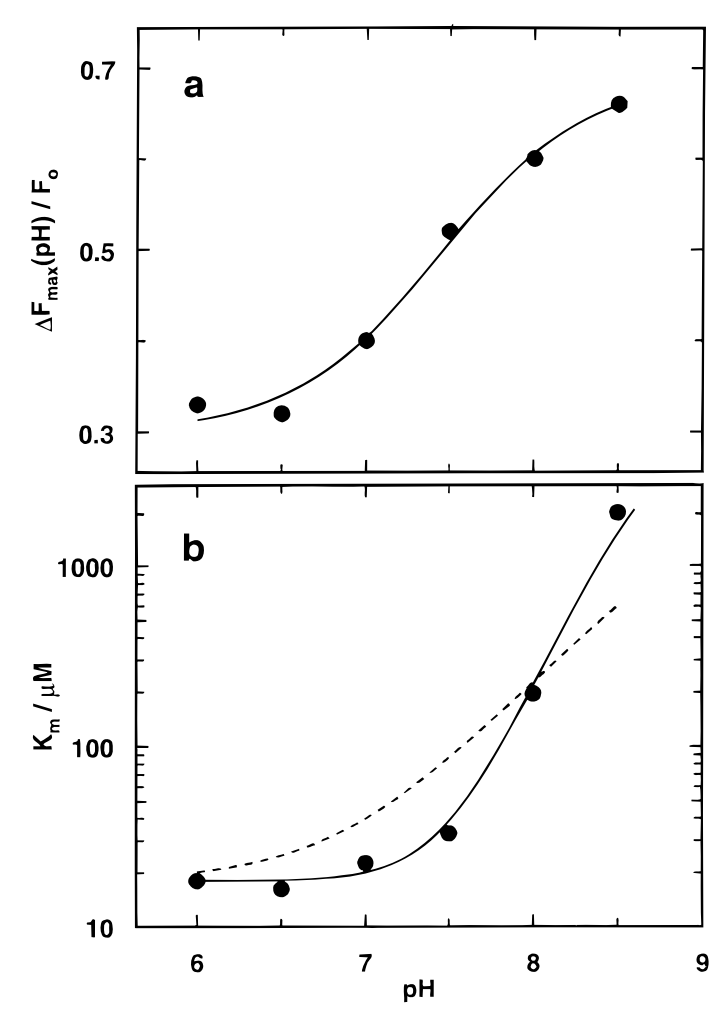

FIGURE 7: Influence of $\mathrm{pH}$ on (a) the maximum fluorescence of RH421 obtained after ATPase phosphorylation by $\mathrm{P}_{\mathrm{i}}$ and (b) on equilibrium binding of $\mathrm{P}_{\mathrm{i}}$ to the ATPase. In (a) experiments as shown in Figure 2 were analyzed to obtain the maximum fluorescence increase, $\Delta F_{\max } / F_{0}$, at a given $\mathrm{pH}$. The line drawn is a fit to a simple binding isotherm with $\mathrm{p} K$ of 7.5 and a $\Delta F_{\max } / F_{0}$ of 0.7 at high $\mathrm{pH}$ values. The fluorescence intensity ratio $\left(\Delta F_{\max } / F_{0}\right)$ represents the condition when virtually all protein is phosphorylated. In (b) the half-saturating $\mathrm{P}_{\mathrm{i}}$ concentration dependence on $\mathrm{pH}$ derived from experiments as in Figure 6 is shown. The lines drawn represent fits of Hill functions with Hill coefficients $n_{\mathrm{H}}=2$ with $\mathrm{p} K 8.6$ (solid line) and $n_{\mathrm{H}}=1$ with $\mathrm{p} K 9.2$ (dashed line).

observed which can be reproduced by a Hill curve with a Hill coefficient of 2 and $\mathrm{p} K_{\mathrm{a}}$ of 8.6.

To check the possible $\mathrm{pH}$ dependence of the phosphorylation step, $\mathrm{E}_{2}+\mathrm{P}_{\mathrm{i}} \rightarrow \mathrm{P}-\mathrm{E}_{2}$ or $\mathrm{E}_{2}\left(\mathrm{H}_{2}\right)+\mathrm{P}_{\mathrm{i}} \rightarrow \mathrm{P}-\mathrm{E}_{2}\left(\mathrm{H}_{2}\right)$, the fast phase of enzyme phosphorylation was determined by experiments as presented in Figure 4 in buffers of $\mathrm{pH}$ in the range 6.5-8.5. The concentration of $\mathrm{P}_{\mathrm{i}}$, photoreleased from caged $\mathrm{P}_{\mathrm{i}}$, was $37 \mu \mathrm{M}$ (data not shown). The relaxation rate $k=8.6 \pm 0.16 \mathrm{~s}^{-1}$ was constant over the whole $\mathrm{pH}$ range studied and agreed with the value from Figure 5 at 37 $\mu \mathrm{M}$ released $\mathrm{P}_{\mathrm{i}}$. The amplitude of the fast component of fluorescence was $\mathrm{pH}$ dependent. It decreased with increasing $\mathrm{pH}$ according to a binding isotherm $(\mathrm{p} K=7.6)$ with the fluorescence at $\mathrm{pH} 6.5$ being 6.5 -fold greater than at $\mathrm{pH} 8.5$. The $\mathrm{pH}$ independence of the rate constants and the $\mathrm{pH}$ dependence of the amplitude of the fluorescence change of the relaxation toward a new steady state in the process $\mathrm{E}_{2}+$ $\mathrm{P}_{\mathrm{i}} \rightleftarrows \mathrm{P}-\mathrm{E}_{2}$ allowed the conclusion that the state of $\mathrm{E}_{2}$ contributing to the observed fluorescence change is controlled by $\mathrm{pH}$, e.g., as $\mathrm{E}_{2}\left(\mathrm{H}_{2}\right)$.

In addition we found that the overall fluorescence change, $\Delta F_{\max } / F_{0}$ (Figure $7 \mathrm{a}$ ), a steady state parameter, is the sum of the contributions of the fast and slow phases of the enzyme phosphorylation kinetics. The different $\mathrm{pH}$ dependence of both phases is reflected in their contribution to $\Delta F_{\max } / F_{0}$. At pH 6-6.5 the fluorescence change is generated predomi- 
nantly by the fast phase $\left(\Delta F_{\text {fast }} / F_{0} \approx 0.7 \Delta F_{\text {max }} / F_{0}\right)$. At $\mathrm{pH}$ 8.5 the overall fluorescence change is carried mainly by the slow phase $\left(\Delta F_{\text {slow }} / F_{0} \approx 0.95 \Delta F_{\text {max }} / F_{0}\right)$. These findings are in agreement with the $\mathrm{pH}$ dependence of the population of state $\mathrm{E}_{2}\left(\mathrm{H}_{2}\right)$ before phosphorylation.

\section{DISCUSSION}

In the present experiments the previously reported backdoor phosphorylation of the Na,K-ATPase (Post et al., 1975; Campos \& Beaugé, 1994) was detected by an optical method, which was previously applied successfully to other electrogenic partial reactions of the ion-transport cycle (Stürmer at al., 1991; Heyse et al. 1994). The reaction sequence $E_{1} \rightarrow$ $\mathrm{E}_{2} \rightarrow \mathrm{P}-\mathrm{E}_{2}$ is expected to be strongly electrogenic when the ion-binding sites are unoccupied during the process (Wuddel \& Apell, 1995). The movement of two uncompensated negative charges in the ion-binding sites, which are close to the extracellular aqueous phase in state $\mathrm{P}-\mathrm{E}_{2}$ and on the dielectric surface of the cytoplasmic side in state $E_{1}$, could contribute significantly to the energetics of this partial reaction. Therefore the experiments were designed to determine both the kinetics of the reaction pathway and a possible occupation of the binding sites.

We have characterized a two-step process on addition of $P_{i}$ to the Na,K-ATPase that we have interpreted in terms of $E_{1}$ and $E_{2}$ states as in reactions 1 and 2. The interpretation that the more rapid phase is associated with $P_{i}$ interacting with the $E_{2}$ state appears straightforward. However, as noted in the Results, the distinctly different character of the $E_{1}$ states described here and by Smirnova et al. (1995) means that much still has to be learnt about subpopulations among the various conformations of the ATPase. In addition, while reactions 1 and 2 are a plausible description of the mechanism of back-door phosphorylation, in the literature additional states are inferred from oxygen exchange data. Thus a state, presumably $\mathrm{E}_{2} \cdot \mathrm{P}_{\mathrm{i}}$, is implied because intermediate oxygen exchange is observed during $\mathrm{Na}, \mathrm{K}-\mathrm{ATPase}$ activity (Dahms et al., 1973; Skvortsevich et al., 1973). Furthermore the bound $\mathrm{P}_{\mathrm{i}}$ in $\mathrm{E}_{2} \cdot \mathrm{P}_{\mathrm{i}}$ must undergo some form of isomerization, such as rotation within its binding site (Trentham et al., 1976).

Origin of the RH421 Fluorescence Changes. Recent publications dealt with the mechanism of the RH421 fluorescence changes observed on different proteins and membrane preparations and especially $\mathrm{Na}, \mathrm{K}-\mathrm{ATPase}$ containing membrane preparations similar to ours (Visser et al., 1995; Fedosova et al., 1995). Their findings demonstrate that conformational transitions of the protein cannot be excluded. Therefore we checked the effect of the conformational transition $\mathrm{E}_{1} \rightleftarrows \mathrm{E}_{2}$ and the effect of $\mathrm{pH}$ variation on the RH421 fluorescence. At pH 7.1 in the absence of $\mathrm{Na}^{+}$and $\mathrm{K}^{+}$ions and in the presence of $\mathrm{Mg}^{2+}$ ions in the millimolar range the enzyme is predominantly in its $\mathrm{E}_{1}$ conformation (Grell et al., 1991). Addition of $20 \mathrm{mM} \mathrm{K}^{+}$ ions transfers the protein quantitatively in to state $\mathrm{E}_{2}\left(\mathrm{~K}_{2}\right)$ (Karlish, 1980) and addition of saturating $P_{i}$ also populates the state $\mathrm{P}-\mathrm{E}_{2} \mathrm{~K}_{2}$ (Karlish \& Stein, 1982). Due to the high affinity of the $\mathrm{P}-\mathrm{E}_{2}$ states for $\mathrm{K}^{+}$the binding sites will remain occupied under these conditions. Tracing this reaction sequence by RH421, no significant fluorescence changes are observed. When the RH421 is monitored with membrane fragments beginning at $\mathrm{pH} 8$ and subsequently adding $\mathrm{H}^{+}$(to reach $\mathrm{pH}$ 6.5) again no changes in fluorescence intensity are observed. When ATP is added to enzyme in state $\mathrm{E}_{2}\left(\mathrm{~K}_{2}\right)$, the reaction $\mathrm{E}_{2}\left(\mathrm{~K}_{2}\right) \rightarrow \mathrm{E}_{1} \mathrm{ATP}$ is triggered and again no change of RH421 fluorescence was observed (Stürmer et al., 1991b; Klodos, 1994). All these findings indicate that RH421 fluorescence does not report the conformational transition $\mathrm{E}_{1} \rightleftarrows \mathrm{E}_{2}$. Back-door phosphorylation in the presence of $\mathrm{K}^{+}$is also a reaction step which is not detected by RH421 fluorescence. Since this reaction occurs at parts of the protein exposed to the cytoplasm, we conclude by analogy that in the absence of $\mathrm{K}^{+}$and the presence of $\mathrm{H}^{+}$the same is valid.

The consequence of these observations is that the only remaining reaction step, the extracellular binding/release of $\mathrm{H}^{+}$, is detected by $\mathrm{RH} 421$. This is in agreement with the observation that the binding and release of $\mathrm{Na}^{+}$and $\mathrm{K}^{+}$are detected by RH421 (Stürmer et al., 1991a; Bühler \& Apell, $1995)$ and with the $\mathrm{pH}$ titration of the steady state fluorescence of the back-door-phosphorylated enzyme (Figure 7a). The fluorescence changes observed in the back-door phosphorylation experiments as presented in Figures 1, 3, and 4 are therefore produced by subsequent (electrogenic) proton release from the extracellulary accessible binding sites. Due to the fact that ion-binding and release steps are fast processes compared to the precursor steps the RH421 fluorescence changes represent the undistorted kinetics of the electrically silent steps, $\mathrm{E}_{1} \rightleftarrows \mathrm{E}_{2}+\mathrm{P}_{\mathrm{i}} \rightleftarrows \mathrm{P}-\mathrm{E}_{2}$.

Detection of RH421 Fluorescence Changes by Addition of $P_{i}$. In earlier studies of the back-door phosphorylation the existence of state $\mathrm{P}-\mathrm{E}_{2}$ was detected by an acid-stable binding of ${ }^{32} \mathrm{P}$ to the enzyme (Post et al., 1975; Campos \& Beaugé, 1994). Therefore experiments corresponding to previously published findings on phosphorylation from $\mathrm{P}_{\mathrm{i}}$ had to be performed to ensure that the observed fluorescence changes are specific. Crucial control experiments were that the fluorescence increase occurred only when $\mathrm{P}_{\mathrm{i}}$ was added in the presence of $\mathrm{Mg}^{2+}$ but in the absence of high $\mathrm{Na}^{+}$ and ATP. Subsequent addition of ATP or $\mathrm{Na}^{+}$reversed the $\mathrm{P}_{\mathrm{i}}$-induced fluorescence increase (Figure 1) as it reversed enzyme phosphorylation (Campos \& Beaugé, 1994). The $P_{i}$ concentration dependence of the RH421 fluorescence levels could be fitted by a simple binding isotherm with a half-saturating concentration, $K_{\mathrm{m}}$, of $23.2 \mu \mathrm{M}$ (Figure 2) which is in reasonable agreement with a previous value of $32 \mu \mathrm{M}$ for the half-saturating concentration for back-door phosphorylation of pig kidney enzyme (Campos \& Beaugé, 1994).

Determination of Rate Constants. $\mathrm{P}_{\mathrm{i}}$ concentration jumps produced by laser flash photolysis of caged $P_{i}$ allowed synchronization of the phosphorylation reaction. The dependence of the protein-induced fluorescence signal on the concentration of released $\mathrm{P}_{\mathrm{i}}$ was linear according to a onestep reaction. Together with the data collected by manual addition of $\mathrm{P}_{\mathrm{i}}$ (Figure 3 ) the reaction sequence may be split into a conformational change and an enzyme phosphorylation/dephosphorylation, as described by reactions 1 and 2 with values of rate constants listed in Table 1 . Using ${ }^{32} \mathrm{P}$ studies Campos and Beaugé (1992) measured $k_{-2}$ to be 1.9 $\mathrm{s}^{-1}$, a value comparable to ours. The overall equilibrium dissociation constant for the reactions 1 and 2 is given by $k_{-2}\left(1+k_{-1} / k_{+1}\right) / k_{+2}=29( \pm 3) \mu \mathrm{M}$ where the error was calculated from the sum of sem's. The result is in satisfactory agreement with the value of $23.0 \pm 0.3 \mu \mathrm{M}$ obtained 
Table 1: Rate Constants (Values \pm SEM) of the Reaction Steps Involved in Back-Door Phosphorylation at $20 \pm 1{ }^{\circ} \mathrm{C}$ and $\mathrm{pH} 7.1$

\begin{tabular}{lccc}
\hline \multicolumn{1}{c}{ reaction } & $\begin{array}{c}\text { rate } \\
\text { constant }\end{array}$ & \multicolumn{1}{c}{ value } & determination \\
\hline $\mathrm{E}_{1} \rightarrow \mathrm{E}_{2}$ & $k_{+1}$ & $0.059( \pm 0.003) \mathrm{s}^{-1}$ & Figure 3 \\
$\mathrm{E}_{2} \rightarrow \mathrm{E}_{1}$ & $k_{-1}$ & $0.10( \pm 0.005) \mathrm{s}^{-1}$ & see text \\
$\mathrm{P}_{\mathrm{i}}+\mathrm{E}_{2} \rightarrow$ & $k_{+2}$ & $1.47( \pm 0.05) \times$ & Figure 5 \\
$\mathrm{P}-\mathrm{E}_{2}+\mathrm{H}_{2} \mathrm{O}$ & & $10^{5} \mathrm{M}^{-1} \mathrm{~s}^{-1}$ & \\
$\mathrm{H}_{2} \mathrm{O}+\mathrm{P}-\mathrm{E}_{2} \rightarrow$ & $k_{-2}$ & $3.07( \pm 0.17) \mathrm{s}^{-1}$ & Figure 5 \\
$\mathrm{E}_{2}+\mathrm{P}_{\mathrm{i}}$ & & & \\
\hline
\end{tabular}

from equilibrium experiments. This finding, in addition to equilibrium experiments in the presence of up to $650 \mu \mathrm{M}$ caged $\mathrm{P}_{\mathrm{i}}$ in which $K_{\mathrm{m}}$ values of about $25 \pm 0.6 \mu \mathrm{M}$ were found, indicates that the presence of the caged compound does not affect the measured rate of phosphorylation.

It has been shown that the conformational change $\mathrm{E}_{2} \rightarrow$ $\mathrm{E}_{1}$ could be accelerated by ATP binding to a low-affinity site as in the case of $\mathrm{K}^{+}$transport (Campos \& Beaugé, 1994). A corresponding experiment with our preparation was performed (Figure 1a) and showed a fast drop of the fluorescence intensity to a level which was equivalent to the state $\mathrm{E}_{1} \cdot \mathrm{ATP}$ (Figure 1c).

Dependence of Back-Door Phosphorylation on $\mathrm{pH}$. The same $\mathrm{P}-\mathrm{E}_{2}$ state is reached by phosphorylation from $\mathrm{P}_{\mathrm{i}}$ or ATP (Bonting et al., 1979; Fedosova et al., 1995) but the difference in the fluorescence levels reached by phosphorylation from $\mathrm{P}_{\mathrm{i}}$ or from ATP $+\mathrm{Na}^{+}$(Figure 1) was significant. The $\mathrm{P}_{\mathrm{i}}$-induced signal change at $\mathrm{pH} 7.1$ reached only $55 \%$ of that generated by a near-complete phosphorylation from ATP. This observation may be explained either by the fact that $\mathrm{P}_{\mathrm{i}}$ leads only to a partial population of state $\mathrm{P}-\mathrm{E}_{2}$ in contrast to phosphorylation by ATP or by partial occupation of the negatively charged ion-binding sites by cations. According to the $K_{\mathrm{m}}$ of the enzyme phosphorylation from $\mathrm{P}_{\mathrm{i}}$ (Figure 2), at $500 \mu \mathrm{M} \mathrm{P}_{\mathrm{i}}$ more than $95 \%$ of the protein should be phosphorylated. Therefore the argument of partial phosphorylation can be excluded. Since it is known that cation binding to state $\mathrm{P}-\mathrm{E}_{2}$ leads to a decrease of the RH421 fluorescence (Stürmer et al., 1991a; Bühler \& Apell, 1995), it was necessary to check whether such a phenomenon occurred. Protons were the only monovalent cations available in these experiments, and the effect of $\mathrm{pH}$ on the equilibrium binding of $P_{i}$ was determined (Figures 6 and 7). The dependence of RH421 fluorescence on $\left[\mathrm{P}_{\mathrm{i}}\right]$ could be fitted at all $\mathrm{pH}$ values with a simple binding isotherm (Figure 6). The $\mathrm{pH}$ dependence of $\Delta F_{\max } / F_{0}$ in the absence of $\mathrm{Na}^{+}$ ions can be explained by a titration of the extracellularlypresented ion-binding sites with one $\mathrm{H}^{+}$ion. The $\mathrm{p} K$ of this process was 7.5 (Figure 7a). Above $\mathrm{pH} 8$ the intensity of $\Delta F_{\max } / F_{0}$ approached the level obtained by ATP phosphorylation in low concentrations of $\mathrm{Na}^{+}$. At low $\mathrm{pH}$ the value of $\Delta F_{\max } / F_{0}$ is 0.3 , which corresponds approximately to a reduction of the net charge in the binding sites to one negative charge (Bühler \& Apell, 1995). The half-saturating $\mathrm{P}_{\mathrm{i}}$ concentration shows cooperative $\mathrm{pH}$ dependence (Figure $7 b)$. The $\mathrm{pH}$ dependence may be accepted as indirect evidence for the role of $\mathrm{H}^{+}$as congeners for $\mathrm{K}^{+}$or $\mathrm{Na}^{+}$ions in the $\mathrm{P}-\mathrm{E}_{2} \rightarrow \mathrm{E}_{1}$ pathway, which has been proposed previously (Polvani \& Blostein, 1988). Goldschleger et al. (1990) reported from experiments with $\mathrm{Na}, \mathrm{K}$-ATPase reconstituted in vesicles that in $\mathrm{Na}^{+}$and $\mathrm{K}^{+}$free extracellular buffers the transport of cytoplasmic $\mathrm{Na}^{+}$was $\mathrm{pH}$ dependent.
Scheme 2: Modified Pump Reaction Scheme of the $\mathrm{Na}, \mathrm{K}-\mathrm{ATP}$ ase in the Absence of $\mathrm{K}^{+}$Ions $^{a}$

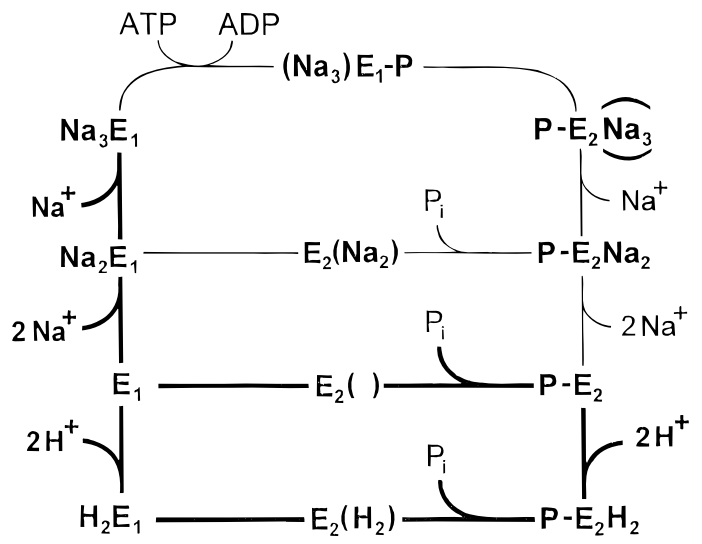

${ }^{a}$ The broad lines refer to possible pathways in the absence of ATP. The state $E_{2}($ ) indicates occluded empty ion binding sites. The partial reaction $\mathrm{P}-\mathrm{E}_{2} \rightarrow \mathrm{P}-\mathrm{E}_{2} \mathrm{Na}_{2}$ can be excluded when the $\mathrm{Na}^{+}$concentration is below $100 \mathrm{mM}$, since the equilibrium dissociation constant is greater than $1 \mathrm{M}$ (Heyse et al., 1994). The direct transition from $\mathrm{E}_{1} \rightarrow \mathrm{P}-\mathrm{E}_{2}$ seemed to be extremely slow and hardly contributes to the observed effects.

Below $\mathrm{pH} 7$ it was electroneutral and in $\mathrm{pH}$ range 7.5-8.5 it was electrogenic. A similar $\mathrm{pH}$-dependent influence on the reaction $\mathrm{P}-\mathrm{E}_{2} \rightarrow \mathrm{E}_{1}$ was found in electric measurements (Wuddel, 1994).

Proposal of a Reaction Scheme of the Back-Door Phosphorylation. In Scheme 2 a modified Post-Albers scheme is presented for the Na-only mode of the Na,K-ATPase. The bold lines represent the pathways which may occur in the presence of $\mathrm{P}_{\mathrm{i}}$ but in the absence of ATP.

In the $E_{1}$ conformation of the pump the presence of 50 $\mathrm{mM} \mathrm{Na}{ }^{+}$causes a shift of the steady state to $\mathrm{Na}_{3} \mathrm{E}_{1}(87 \%)$, while state $\mathrm{E}_{1}$ is populated by less than $0.1 \%$ (Schulz \& Apell, 1995). This condition gives reason for the apparent dephosphorylation of the enzyme upon addition of $\mathrm{Na}^{+}$.

According to Scheme 2 three possible dephosphorylation pathways may occur in principle: Firstly, a dephosphorylation of the pump can occur through the reaction sequence $\mathrm{P}-\mathrm{E}_{2} \rightarrow \mathrm{P}-\mathrm{E}_{2} \mathrm{Na}_{2} \rightarrow \mathrm{E}_{2}\left(\mathrm{Na}_{2}\right) \rightarrow \mathrm{Na}_{2} \mathrm{E}_{1} \rightarrow \mathrm{Na}_{3} \mathrm{E}_{1}$. In the presence of low $\mathrm{Na}^{+}(\leq 50 \mathrm{mM})$ this pathway is unlikely to contribute. The sodium affinity of the phosphorylated states of $\mathrm{E}_{2}$ is so low that the population of state $\mathrm{P}-\mathrm{E}_{2} \mathrm{Na}_{2}$ can be calculated to be less than 1\% (Heyse et al., 1994; Wuddel, 1994). The two other possible pathways are $\mathrm{P}-\mathrm{E}_{2} \rightarrow \mathrm{E}_{2}($ ) $\rightarrow \mathrm{E}_{1}$, in which two (empty) negatively charged binding sites are occluded within the protein and transferred to the cytoplasmic side of the protein, and as an alternative possibility the reaction sequence $\mathrm{P}-\mathrm{E}_{2} \rightarrow \mathrm{P}-\mathrm{E}_{2}\left(\mathrm{H}_{2}\right) \rightarrow$ $\mathrm{E}_{2}\left(\mathrm{H}_{2}\right) \rightarrow \mathrm{H}_{2} \mathrm{E}_{1} \rightarrow \mathrm{E}_{1}$ may contribute in which protons are transported as congeners of $\mathrm{K}^{+}$ions. Selection between the pathways will be controlled by the $\mathrm{pH}$. From experimental evidence as presented in Figure $7 \mathrm{~b}$ it can argued that the pathway with empty binding sides may contribute also to a lesser extent to back-door phosphorylation/dephosphorylation reactions: At high buffer $\mathrm{pH}(>7.5)$ extremely high $\mathrm{P}_{\mathrm{i}}$ concentrations are necessary to shift the steady state of the enzyme to $\mathrm{P}-\mathrm{E}_{2}$. A possible explanation is the following. With increasing $\mathrm{pH}$ the reaction $\mathrm{E}_{1} \rightarrow \mathrm{H}_{2} \mathrm{E}_{1}$ and $\mathrm{P}-\mathrm{E}_{2} \rightarrow$ $\mathrm{P}-\mathrm{E}_{2} \mathrm{H}_{2}$ will become less probable and consequently $\mathrm{E}_{1} \rightleftarrows$ $\mathrm{E}_{2}\left(\mathrm{)} \rightleftarrows \mathrm{P}-\mathrm{E}_{2}\right.$ is the sole pathway. In the absence of bound ions, the rate of the conformational transition $\mathrm{E}_{1} \rightarrow \mathrm{E}_{2}($ ) 
may be very low and the steady state shifted to the state $\mathrm{E}_{1}$ since electrogenicity of this reaction step is very high. According to Wuddel and Apell (1995) it has a dielectric coefficient of 1.8: thus the state $\mathrm{E}_{2}(\mathrm{)})$ is sparsely populated, and the reaction $\mathrm{E}_{2}()+\mathrm{P}_{\mathrm{i}} \rightarrow \mathrm{P}-\mathrm{E}_{2}$ would not contribute significantly. In the $\mathrm{H}^{+}$dependent pathway the population of state $\mathrm{E}_{2}\left(\mathrm{H}_{2}\right)$ depends on the square of the $\mathrm{H}^{+}$concentration and consequently higher $\mathrm{pH}$ requires higher concentrations of $\mathrm{P}_{\mathrm{i}}$ to reach half-saturation of the state $\mathrm{P}-\mathrm{E}_{2}$ in the reaction $\mathrm{E}_{2}\left(\mathrm{H}_{2}\right)+\mathrm{P}_{\mathrm{i}} \rightleftarrows \mathrm{P}-\mathrm{E}_{2} \mathrm{H}_{2}$. The $K_{\mathrm{m}}$ for $\mathrm{P}_{\mathrm{i}}$ has been found to be cooperative in $\left[\mathrm{H}^{+}\right]$(Figure $7 \mathrm{~b}$ ), which may be accepted as evidence for this mechanism.

The independence of the phosphorylation kinetics on $\mathrm{pH}$ in the range 6.5-8.5 demonstrated that changes in nonspecific protein protonation or protonation of inorganic phosphate, $\mathrm{P}_{\mathrm{i}}$, did not interfere with the phosphorylation reaction. The effect of $\mathrm{pH}$ on the fluorescence amplitude of this step, however, supported the assumption by independent evidence that the binding sites are occupied by protons during backdoor phosphorylation. As already noted the fluorescence amplitudes of the slow and the fast phases of the fluorescence changes such as in Figure 3 depend strongly on $\mathrm{pH}$. At $\mathrm{pH}$ 8.5 the fluorescence amplitude of the fast process was less than $5 \%$ of the overall fluorescence change on $\mathrm{P}_{\mathrm{i}}$ addition. The amplitude of the fast process depends primarily on the population of state $\mathrm{E}_{2}\left(\mathrm{)}\right.$ or $\mathrm{E}_{2}\left(\mathrm{H}_{2}\right)$. Only the latter is controlled by $\mathrm{pH}$ via $\mathrm{E}_{1}+2 \mathrm{H}^{+} \rightleftarrows \mathrm{H}_{2} \mathrm{E}_{1} \rightleftarrows \mathrm{E}_{2}\left(\mathrm{H}_{2}\right)$ and will produce the observed $\mathrm{pH}$ dependence.

Summarizing all this evidence the pathway $\mathrm{E}_{1} \rightleftarrows \mathrm{H}_{2} \mathrm{E}_{1} \rightleftarrows$ $\mathrm{H}_{2} \mathrm{E}_{2} \rightleftarrows \mathrm{P}-\mathrm{E}_{2} \mathrm{H}_{2}$ (lower track in Scheme 2) may be proposed as the most probable reaction sequence for the back-door phosphorylation/dephosphorylation in the absence of $\mathrm{Na}^{+}$and $\mathrm{K}^{+}$ions. Under these conditions the rate constants given in Table 1 reflect the parameters of the pathway $\mathrm{H}_{2} \mathrm{E}_{1} \rightleftarrows \mathrm{H}_{2} \mathrm{E}_{2}$ $\rightleftarrows \mathrm{P}-\mathrm{E}_{2} \mathrm{H}_{2}$.

\section{ACKNOWLEDGMENT}

We thank Dr. Rupert Bühler for helpful discussions and Gabi Witz for excellent technical assistance. We are grateful to Dr. Martin Webb for advice on measurement of inorganic phosphate and for the gift of reagents.

\section{REFERENCES}

Apell, H.-J. (1989) J. Membr. Biol. 110, 103-114.

Apell, H.-J., Häring, V., \& Roudna, M. (1990) Biochim. Biophys. Acta 1023, 81-90.

Berberián, G., \& Beaugé, L. (1991) Biochim. Biophys. Acta 1063, 217-225.

Bonting, S. L., Schuurmans Stekhoven, F. M. A. H., Swarts, H. G. P., \& De Pont, J. J. H. H.M. (1979) in Na,K-ATPase: Structure and Kinetics (Skou, J. C., \& Nørby, J. G., Eds.) pp 317-330, Academic Press, New York.

Borlinghaus, R., \& Apell, H.-J. (1988) Biochim. Biophys. Acta 939, 197-206.

Bühler, R., \& Apell, H.-J. (1995) J. Membr. Biol. 145, 165-173.

Bühler, R., Stürmer, W., Apell, H.-J., \& Läuger, P. (1991) J. Membr. Biol. 121, 141-161.

Campos, M., \& Beaugé, L. (1992) Biochim. Biophys. Acta 1105, $51-60$.

Campos, M., \& Beaugé, L. (1994) J. Biol. Chem. 269, 1802818036.

Cornelius, F. (1995) Biochim. Biophys. Acta 1235, 197-204.

Corrie, J. E. T., Reid, G. P., Trentham, D. R., Hursthouse, M. B., \& Mazid, M. A. (1992) J. Chem. Soc., Perkin Trans. 1, 10151019.
Corrie, J. E. T., \& Trentham, D. R. (1992) J. Chem. Soc., Perkin Trans. 1, 2409-2417.

Dahms, A. S., Kanazawa, T., \& Boyer, P. D. (1973) J. Biol. Chem. 248, 6592-6595.

Dantzig, J. A., Goldman, Y. E., Millar, N. C., Lacktis, J., \& Homsher, E. (1992) J. Physiol. 451, 247-278.

Fedosova, N. U., Cornelius, F., \& Klodos, I. (1995) Biochemistry 34, 16806-16814.

Forbush, B., III (1984) Proc. Natl. Acad. Sci. U.S.A. 81, 5310-5314.

Glynn, I. M. (1985) in The Enzymes of Biological Membranes: The $\mathrm{Na}^{+}, \mathrm{K}^{+}$-Transporting Adenosine Triphosphatase (Martonosi, A. N., Ed.) pp 35-114, Plenum Publishing Corp., New York.

Goldschleger, R., Shahak, Y., \& Karlish, S. J. D. (1990) J. Membr. Biol. 113, 139-154.

Grell, E., Warmuth, R., Lewitzki, E., \& Ruf, H. (1991) in The Sodium Pump: Recent Developments (Kaplan, J. H., \& De Weer, P., Eds.) pp 441-445, The Rockefeller University Press, New York.

Grinvald, A., Hildesheimer, R., Farber, I. C., \& Anglister, L. (1982) Biophys. J. 39, 301-308.

Heyse, S., Wuddel, I., Apell, H.-J., \& Stürmer, W. (1994) J. Gen. Physiol. 104, 197-240.

Jørgensen, P. L. (1974) Methods Enzymol. 32, 277-290.

Jørgensen, P. L. (1992) in Molecular Aspects of Transport Proteins (De Pont, J. J., Ed.) pp 1-26, Elsevier Science Publishers BV, Amsterdam, The Netherlands.

Kaplan, J. H., Forbush, B., \& Hoffman, J. F. (1978) Biochemistry 17, 1929-1935.

Karlish, S. J. D. (1980) J. Bioenerg. Biomembr. 12, 111-136.

Klodos, I. (1994) in The Sodium Pump: Structure, Mechanism, Hormonal Control and Its Role in Disease (Bamberg, E., \& Schoner, W., Eds.) pp 517-528, Steinkopff Verlag, Darmstadt, Germany.

Läuger, P. (1991) Electrogenic Ion Pumps, Sinauer Associates, Inc., Sunderland, MA.

Lowry, O. H., Rosenbrough, N. J., Farr, A. L., \& Randall, R. J. (1951) J. Biol. Chem. 193, 265-275.

Ovchinnikov, Yu. A., Modyanov, N. N., Broude, N. E., Petrukhin, K. E., Grishin, A. V., Arzamazova, N. M., Aldanova, N. A., Monastyrskaya, G. S., \& Sverdlov, E. D. FEBS Lett. 201 (2), 237-245.

Polvani, C., \& Blostein, R. (1988) J. Biol. Chem. 263, 16757-16763.

Post, R. L., Toda, G., \& Rogers, F. N. (1975) J. Biol. Chem. 250, 691-701.

Schulz, S., \& Apell, H.-J. (1995) Eur. Biophys. J. 23, 413-421.

Schwappach, B., Stürmer, W., Apell, H.-J., \& Karlish, S. D. J. (1994) J. Biol. Chem. 269, 21620-21626.

Schwartz, A., Nagano, K., Nakao, M., Lindenmayer, G. E., \& Allen, J. C. (1971) Methods Pharmacol. 1, 361-388.

Sen, A. K., Tobin, T., \& Post, R. L. (1969) J. Biol. Chem. 244, 6596-6604.

Skvortsevich, E. G., Pantaleeva, N. S., \& Pisareva, L. N. (1973) Dokl. Akad. Sci. SSSR (Biochem.) 206, 363-365.

Smirnova, I. N., Lin, S. H., \& Faller, L. D. (1995) Biochemistry 34, 8657-8667.

Stürmer, W., \& Apell, H.-J. (1992) FEBS Lett. 300, 1-4.

Stürmer, W., Apell, H.-J., Wuddel, I., \& Läuger, P. (1989) J. Membr. Biol. 110, 67-86.

Stürmer, W., Bühler, R., Apell, H.-J., \& Läuger, P. (1991a) J. Membr. Biol. 121, 163-176.

Stürmer, W., Bühler, R., Apell, H.-J., \& Läuger, P. (1991b) in The Sodium Pump: Recent Developments (Kaplan, J. H., \& De Weer, P., Eds.) pp 531-536, The Rockefeller University Press, New York.

Trentham, D. R., Eccleston, J. F., \& Bagshaw, C. R. (1976) Q. Rev. Biophys. 9, 217-281.

Visser, N. V., van Hoek, A., Visser, A. J. W. G., Frank, J., Apell, H.-J., \& Clarke, R. J. (1995) Biochemistry 34, 11777-11784.

Webb, M. R. (1992) Proc. Natl. Acad. Sci. U.S.A. 89, 4884-4887.

Wuddel, I. (1994) Untersuchung kinetischer und dielektrischer Eigenschaften der Na,K-ATPase: Hemmstoff- und LadungspulsExperimente, Verlag Shaker, Aachen, Germany.

Wuddel, I., \& Apell, H.-J. (1995) Biophys. J. 69, 909-921.

BI960238T 